\title{
テザー宇宙ロボットの姿勢制御に関する微小重力実験*1 Microgravity Experiment for Attitude Control of a Tethered Space Robot
}

\author{
能見公 博*2 \\ Masahiro NoHMI
}

Key Words : Space Engineering, Robot, Tether, Attitude Control, Microgravity

\begin{abstract}
A tethered space robot, which is connected to a mother spacecraft through a peace of tether, is a new space system proposed in the previous work. The tethered subsystem is envisioned to be a multi-body system for a robot, whose attitude can be controlled under tether tension by its own link motion. This paper discusses about microgravity experiment for a tethered space robot. Design and mechanism of the experimental device, required for the proposed attitude control, were explained. Also, link motion control algorithm was designed for the experimental device. Characteristics of the proposed attitude control were confirmed by microgravity experiment using a drop shaft, which can provide high quality microgravity condition during $4.5 \mathrm{~s}$.
\end{abstract}

\section{1. 緒言}

宇宙開発の進歩に伴い, 軌道上サービスが重要となって きている . 人工衛星の保守・点検はもちろんのこと, 国際宇 宙ステーション, 将来的な軌道上中継基地などに伴い, 光 の需要はますます増加すると予測される．このような軌道 上サービスにおいて，空間を自由に移動できるロボットは， 多種多樣な作業要求に対応できると期待されている ${ }^{1)}$. こ のような背景より，テザー宇宙ロボットを提案している2． テザー宇宙ロボットは, 大型母船から伸展されるテザー先 端に小型ロボットを取り付けたシステムである .

テザーは軽量・収納性のよさから宇宙利用か期待され，古 〈から研究されている ${ }^{3)}$. 従来の研究では, 重力傾斜を利用 した数 $\mathrm{km}$ から数百 $\mathrm{km}$ のテザー伸展が中心であり，伸展 回収制御法として，線形レギュレータを用いた最適制御4)， ミッションファンクション制御5)などか提案されている.ま た , テザー先端機の姿勢を考慮し , テザー伸展位置をブーム により動作させる制御方法も研究されている ${ }^{6}$. 宇宙実証実 験としては, Gemini-Agena プログラム ${ }^{7)}$, 米・伊の共同プ ロジェクトである Tethered Satellite System Project ${ }^{8)}$ が 実施されている . また将来的には Kyusyu-university Tethered Satellite Experiments9) などが計画されている.

これらに対し，軌道上サービスを目的とするテザー宇宙 ロボットは, 伸展長を数 $\mathrm{m}$ から数百 $\mathrm{m}$ 程度と想定してい る.このため伸展方法は, 初速度をテザ一先端機に与える方 法, 例えばキャスティングなどを用いる10). 近年 , このよう な軌道上サービスにテザーを利用するものとして，フォー メーションフライト ${ }^{11)}$, デブリ処理 ${ }^{12)}$, なども考えられて

\footnotetext{
*1 (C) 2005 日本航空宇宙学会

平成 16 年 9 月 30 日原稿受理

*2 香川大学
}

いる.これらの研究を含めて, 従来研究ではテザー先端機 の姿勢制御は, テザー張力, リアクションホイール , スラス タなどを用いているが, テザー宇宙ロボットはテザー張力 を利用したロボット動作による姿勢制御を行う ${ }^{13)}$.これは， テザー先端が複数剛体系により構成されていることを利用 して , テザー先端機の質量中心およびテザー連結位置とテ ザー伸展方向の相対関係を操作することにより，テザー伸 展方向に垂直な二軸回りの, テザ一張力による回転力を制 御するものである.これは地上ロボットはもちろんのこと， 空間浮遊型ロボット ${ }^{14,15)}$ とも異なる新しい手法である.

本論文では，これまでに理論解析を行ってきたテザー宇 宙ロボットについて, 地上における微小重力実験による姿 勢制御法の検証・評価を目的とする .テザー張力による回 転力を空間的に制御するためには, 二自由度関節が必要で あることを考慮して, 姿勢制御に適した関節機構を持つ実 験装置を設計・製作し，弚の制御系を設計した。この空間 的動作が可能な関節機構による制御を行うこと, および微 小テザー張力を利用した姿勢制御は摩擦の影響を大きく受 けるため二次元的な平面実験では十分ではないことを考慮 して, 落下塔において実験カプセルを落下させ微小重力環 境を作り出す, 日本無重量総合研究所 ${ }^{16)}$ において三次元微 小重力実験を実施した . 光して, テザー宇宙ロボットの姿 勢制御に関して，実験解析により，実用面における特徵を 明らかにした 。

\section{2. テザー宇宙ロボット実験装置}

2.1 基本構成 テザー宇宙ロボットの姿勢制御は，口 ボットに作用するテザー張力による回転力を利用する .こ のため, テザー張力方向の軸回りの制御は不可能であり，こ の軸に垂直な二軸の回転力を制御し姿勢制御を行う．第 1 図に,姿勢制御に必要なアームとベースから構成されるモデ 
ルを示す . テザー伸展位置に固定された慣性座標系 $O-x y z$ を $\Sigma_{i}$ とする.ベースに固定され，原点か球関節中心に位 置し, 平衡状態においてテザー伸展方向を二軸とする座標 系 $O-012$ を $\Sigma_{r}$ とする .

テザー張力が作用する状態において, テザー延長線上 (図 中 $z$ 軸上) にロボット質量中心位置がある場合, 安定な平 衡状態となる．第 1 図は平衡状態であり，ここでは球関節 中心とベース質量中心位置を一致させているため, 図中 0 軸および 1 軸回りの任意のベース姿勢を目標とすることが できる．乥して，0 軸および 1 軸回りのアーム動作により， ロボットに作用するテザー張力による回転力を制御し, 姿 勢制御を行うことができる．

このモデルに, さらにロボットとしての機能を追加する ことが可能である．作業用アームをベースに取り付けた場 合, ベース姿勢が制御されていれば，例えば，一般化ヤコ

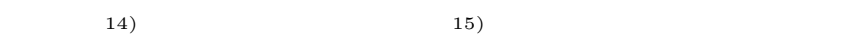
御することが可能である .

2.2 実験装置 テザー宇宙ロボット実験装置は，第 1 図に示す基本モデルをもとに設計・製作した . 第 2 図に実 験装置を示す．テザーはアーム先端に取り付けられる．電 源としてバッテリー (特別仕樣) を搭載し , 自律系とする ことにより外部からの配線をなくし， ロボットに作用する 外力は, アーム先端に作用するテザー張力のみとした . パ ラメータは, 次の通りである .

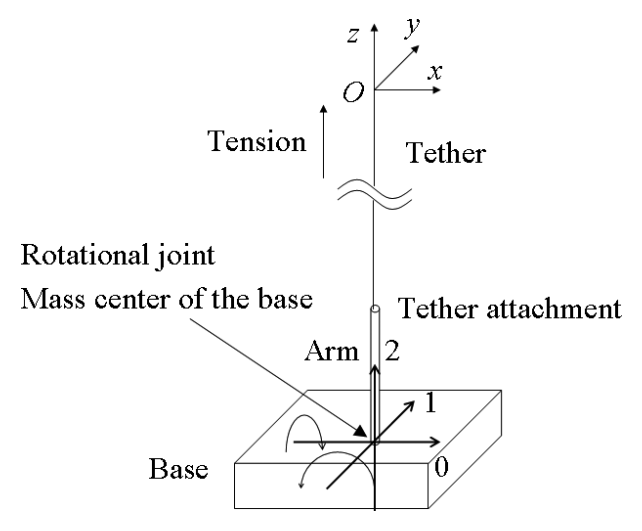

第 1 図 基本構成モデル

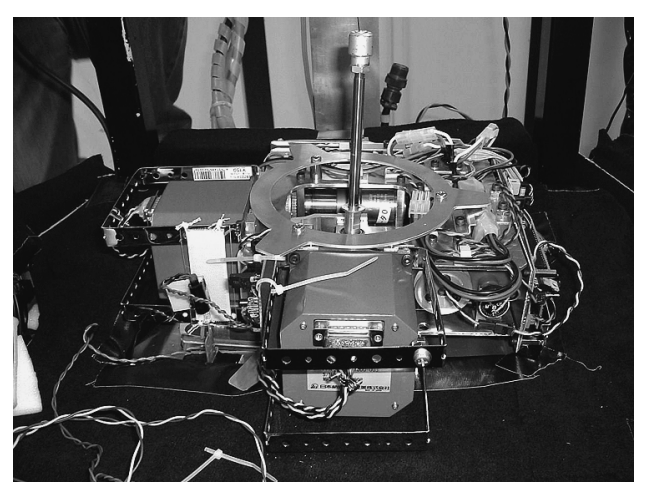

第 2 図 テザー宇宙ロボット実験装置

$$
\begin{array}{ll}
\text { ベース寸法 } & 261 \times 261 \times 82[\mathrm{~mm}] \\
\text { アーム長 } & 100[\mathrm{~mm}] \\
\text { 質量 } & 4.7[\mathrm{~kg}]
\end{array}
$$

実験装置に搭載する制御装置は, 第 3 図に示す構成と なっている.制御は 1 台のマイコン (AKI-H8・秋月電子社 製) を用いて $1 \mathrm{~ms}$ 周期で行う.日本無重量総合研究所で使 用する落下カプセルで実施可能な小型装置を考えると, 姿 勢角検出はジャイロセンサーが適している .ベースにジャ イロセンサー (CRS03-02・シリコンセンシングジャパン社 製または JG-108FD1・日本航空電子社製) を 2 個取り付 け，二軸 ( 0 軸および 1 軸) の角速度 ( $\omega_{0}$ および $\left.\omega_{1}\right)$ を検 出する．アーム関節駆動は， 0 軸および 1 軸に沿って配置 するモータ (3042w012c・FAULHABER 社製) により行 う. 兴の回転角 $\left(\phi_{0}\right.$ および $\left.\phi_{1}\right)$ は, 機械的インターフェー スを介してポテンショメータ (357-2-0・SPECTRO 社製) により検出する . 各データは, 記録装置に保存される .

2.3 アーム関節機構 第 1 図に示す球関節の二軸 $(0$ 軸および 1 軸) をモータにより駆動するため, 第 4 図に示 すように，二つの駆動関節および三つの自由関節，合計五 つの関節から構成される機構を用いる．直交する二軸に二 駆動関節 (関節 1 および関節 2) を配置し，㚇れ光れ同じ 軸に自由関節 (関節 a および関節 b) を配置し，この二軸 の交点をアーム軸とし, 回転自由な関節 (関節 c) により 連結する .この関節機構により，0 軸回りおよび 1 軸回り に , アームを回転させることができる .

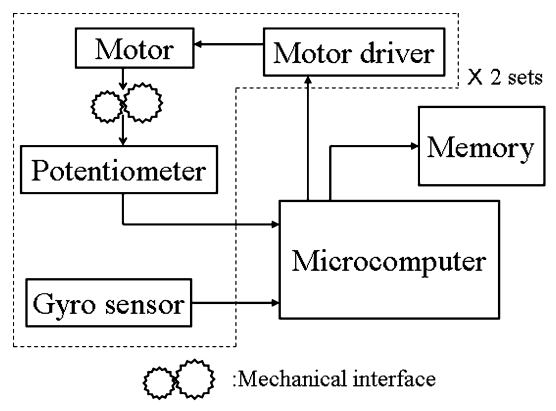

第 3 図 実験装置電子部品構成

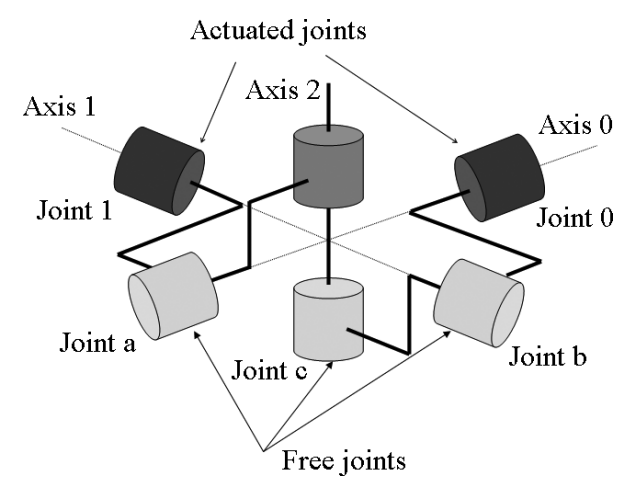

第 4 図 アーム関節機構 


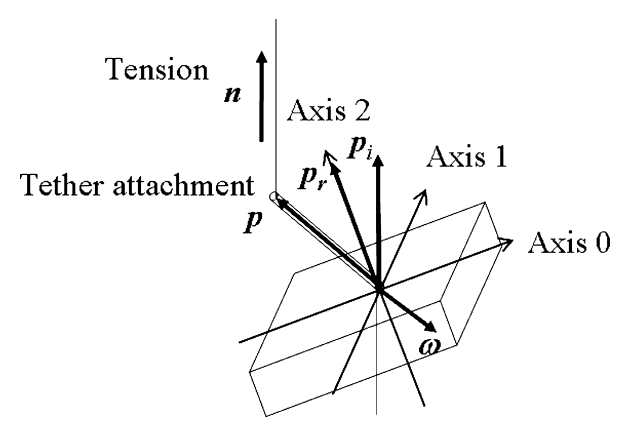

第 5 図 アームとベースの回転運動

\section{3. 姿勢制御手法}

3.1 テザー張力による回転力制御 第 5 図に, 平衡状 態から逸脱した回転運動のようすを示す．ここで，アーム 先端位置ベクトルについて, 第 1 図の平衡状態で慣性座標 系 $\Sigma_{r}$ の $z$ 軸と一致しているものを $\boldsymbol{p}_{i}$, アームが動作し ていない状態でベース固定座標系 $\Sigma_{r}$ の 2 軸と一致してい るものを $\boldsymbol{p}_{r}$, アームが動作している状態のものを $\boldsymbol{p}$ とす る . また , テザー張力ベクトルを $\boldsymbol{n}$, ベース姿勢角速度べ クトルを $\boldsymbol{\omega}=\left[\begin{array}{lll}\omega_{0} & \omega_{1} & \omega_{2}\end{array}\right]^{\mathrm{T}}$ とする .

テザーは柔軟な連続体であり，光の挙動を予測・計測す ることは困難であるため，ロボットに作用するテザー張力 を把握することは難しい . 光こで , テザーはロボットの大 きさに対し十分に長いものとし , またテザー張力は一定と し， $\Sigma_{i}$ 上においてべクトル $\boldsymbol{n}$ は時間によらず一定と仮定 して, 制御系を設計する．また，ベース質量はアーム質量 と比較して十分大きいものとし, アーム動作によるベース への反力は無視する .これより, テザー張力によりロボッ 卜に作用する回転力 $\tau_{r}$ は，

$$
\boldsymbol{\tau}_{r}=\boldsymbol{p} \times \boldsymbol{n}=-\boldsymbol{n} \times \boldsymbol{p}_{r}-\boldsymbol{n} \times\left(\boldsymbol{p}-\boldsymbol{p}_{r}\right)
$$

と表される.式 (1) において, アーム動作により変化する のは $\boldsymbol{p}$ であり, $\boldsymbol{p}_{r}$ および $\boldsymbol{n}$ は変化しない . 第 1 項はべー スが回転することによる平衡状態への復元力であり，アー ム動作がない場合にも発生する.第 2 項はアーム動作によ り変化する回転力であり，この項によりテザー張力による 回転力を制御することができる．

3.2 アーム動作制御 テザー張力方向軸回りの制御は 不可能であることを考慮すると，制御目標は $\boldsymbol{p}_{r}$ を $\boldsymbol{p}_{i}$ に 一致させることとなる .この制御目標に対し単純な PD 制 御を考えると, テザー張力による回転力を復元力と減衰力 を含むものとすることとなる .このため,$\Sigma_{i}$ に対する $\Sigma_{r}$ の姿勢について, 方向が回転軸を表し, 大きさが回転量を 表す回転ベクトル $\Omega$ ，および $\Sigma_{r}$ の角速度ベクトル $\boldsymbol{\omega}$ ， フィードバックする必要がある .

製作した実験装置は，二つのジャイロセンサーにより軸 回りの角速度を検出するため， $\Sigma_{r}$ の 0 軸および 1 軸回り の角速度は検出されるが, 姿勢を検出することは困難であ る.光こで，

$$
\theta_{i}=\int \omega_{i} \mathrm{~d} t, \quad(i=0,1)
$$

として，回転ベクトル $\Omega$ の $i$ 軸成分と仮定する . また，

$$
\boldsymbol{p}-\boldsymbol{p}_{r}=\ell\left[\begin{array}{c}
\phi_{1} \\
-\phi_{0} \\
1
\end{array}\right]
$$

と仮定する .ここで , $\ell$ はアーム長である . 式 (2) および式 (3) の仮定は , ベース姿勢変動およびアーム動作角が微小 であることに基づくものであり，これらが大きい場合，制 御効果に影響を及ぼすことを考慮しなければならない．

テザー張力ベクトルは, $\boldsymbol{n}=\left[\begin{array}{lll}0 & 0 & n\end{array}\right]^{\mathrm{T}}$ と表されること を考慮すると, 式 (2) および式 (3) の仮定を用いると, 式 (1) は次の通り表される .

$$
\boldsymbol{\tau}_{r}=-\boldsymbol{n} \times \boldsymbol{p}_{r}-n \ell\left[\begin{array}{c}
\phi_{0} \\
\phi_{1} \\
0
\end{array}\right]
$$

$k_{p}$ および $k_{d}$ は制御ゲインとして , アーム動作制御式を，

$$
\left[\begin{array}{l}
\phi_{0} \\
\phi_{1}
\end{array}\right]=k_{p}\left[\begin{array}{l}
\theta_{0} \\
\theta_{1}
\end{array}\right]+k_{d}\left[\begin{array}{l}
\omega_{0} \\
\omega_{1}
\end{array}\right]
$$

とすると, 式 (4) は次の通り表される .

$$
\boldsymbol{\tau}_{r}=-\boldsymbol{n} \times \boldsymbol{p}_{r}-n \ell k_{p}\left[\begin{array}{c}
\theta_{0} \\
\theta_{1} \\
0
\end{array}\right]-n \ell k_{d}\left[\begin{array}{c}
\omega_{0} \\
\omega_{1} \\
0
\end{array}\right]
$$

式 (6) において，第 1 項はべース姿勢変化による復元力， 第 2 項はアーム動作による復元力 , 第 3 項はアーム動作に よる減衰力を表している。

ところで, 式 (6) において , アーム動作がない場合でも , $-\boldsymbol{n} \times \boldsymbol{p}_{r}$ による復元力が作用する . これより， $k_{p}=0$ の設 定でも姿勢制御は可能であることがわかる . このとき，復 元力の計算に用いる仮定式 (2) の影響は無く，アーム動作 が大きい場合の減衰効果は, 仮定式 (3) の影響を受けるこ ととなるが, 大きなベース姿勢変動に対しても, 姿勢制御 が可能となる .

微小重力実験は, アーム動作による姿勢制御の基本的特 性を調べることを目的とし，姿勢変動が大きい場合でも適 用可能な $k_{p}=0$ ( $\mathrm{D}$ 制御) を基本とする. これに対し， $k_{d}=0$ ( $\mathrm{P}$ 制御) では復元力のみとなるため振動が発生し， $k_{p}, k_{d} \neq 0$ ( $\mathrm{PD}$ 制御) では目標姿勢への収束性が向上す ることが予測される .

\section{4. 微小重力実験}

4.1 実験施設と伸展回収装置 微小重力実験は日本無 重量総合研究所 (MGLAB) で実施した.MGLAB では落 下塔において実験カプセルを自由落下させ , 約 4.5 秒間の 高精度微小重力空間 $\left(10^{-5} \mathrm{G}\right.$ レベル) を作り出すことが できる . 実験カプセル内に設けられているユーザースペー スは $\phi 720 \mathrm{~mm} \times 885 \mathrm{~mm}$ ，搭載可能最大重量 $400 \mathrm{~kg}$ であ る.また実験カプセルは自由落下後に制動され, 最大加速 


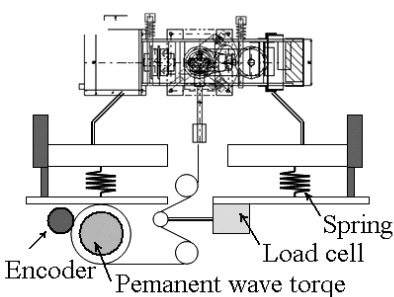

\& Motor

(a) Initial condition under the gravity

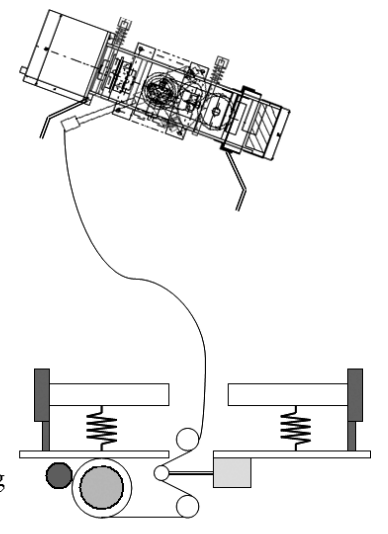

(b) Deployment \& retrieval under microgravity
第6 図 伸展回収装置
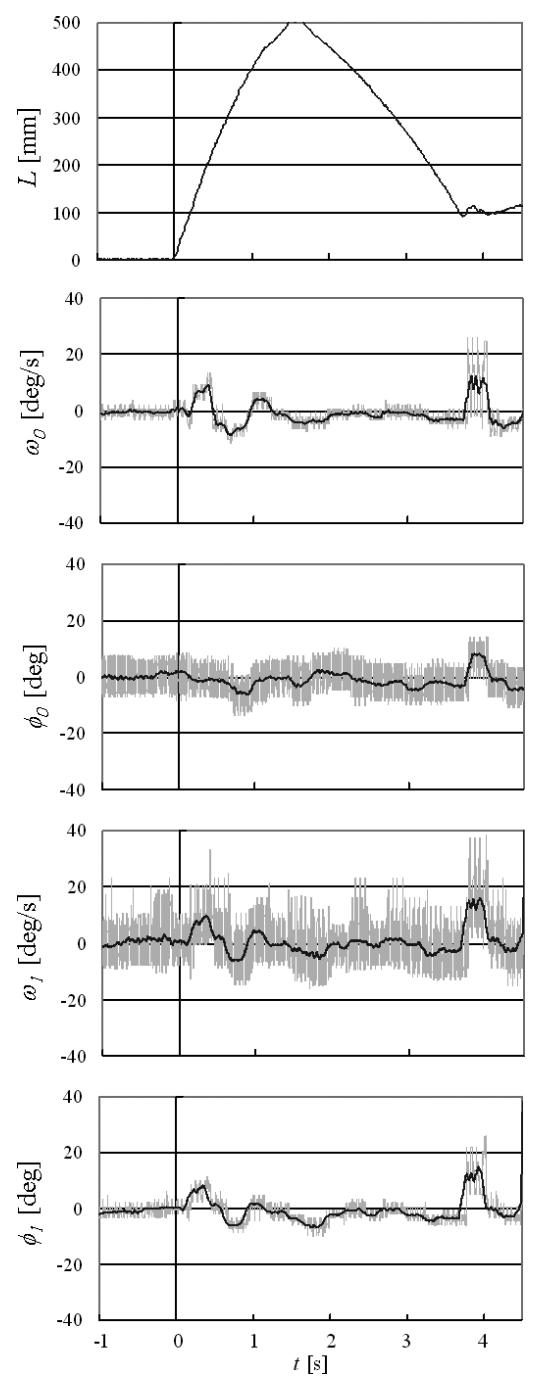

第 7 図Ｄ制御による実験結果

度は $10 \mathrm{G}$ となる。

ロボットは, 第 6 図に示す機構により伸展回収される． この機構では, モータとテザー繰り出し・巻き取り用リール
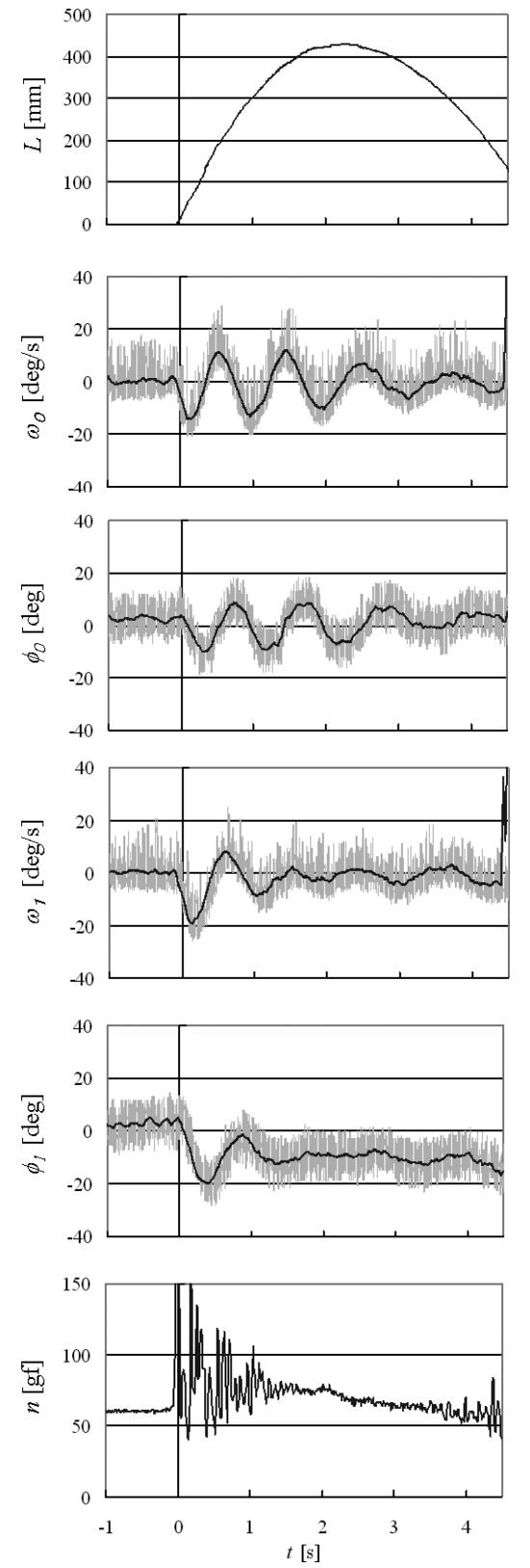

第 8 図 PD 制御による実験結果

の間に , 一定トルクを発生させることができるパーマトル ク (工進精工所社製) を介すことにより，一定テザー張力を 維持することができる .テザー長さはエンコーダ (RE30E・ 日本電産コパル電子株式会社製) により，テザー張力はロー ドセル ( $\mathrm{T} 1$ ・株式会社オリエンテック社製) により測定さ れる.初期状態において，ロボットはばねに支えられたプ レート上に設置される．このとき，ロボット自重によりば ねは圧縮されている，微小重力状態に移行するとロボット 自重はゼロとなり，ばねは伸びることとなる . 結果として ロボットは押し出され (射出), テザーは伸展される．と ころで伸展回収用モータは実験前から終了まで常に駆動し， パーマトルクを介してー定トルクをリールに伝達する .こ のため，ロボットには常に一定のテザー張力が作用し，押 し出されたロボットはやがて停止, 回収されることとなる . 

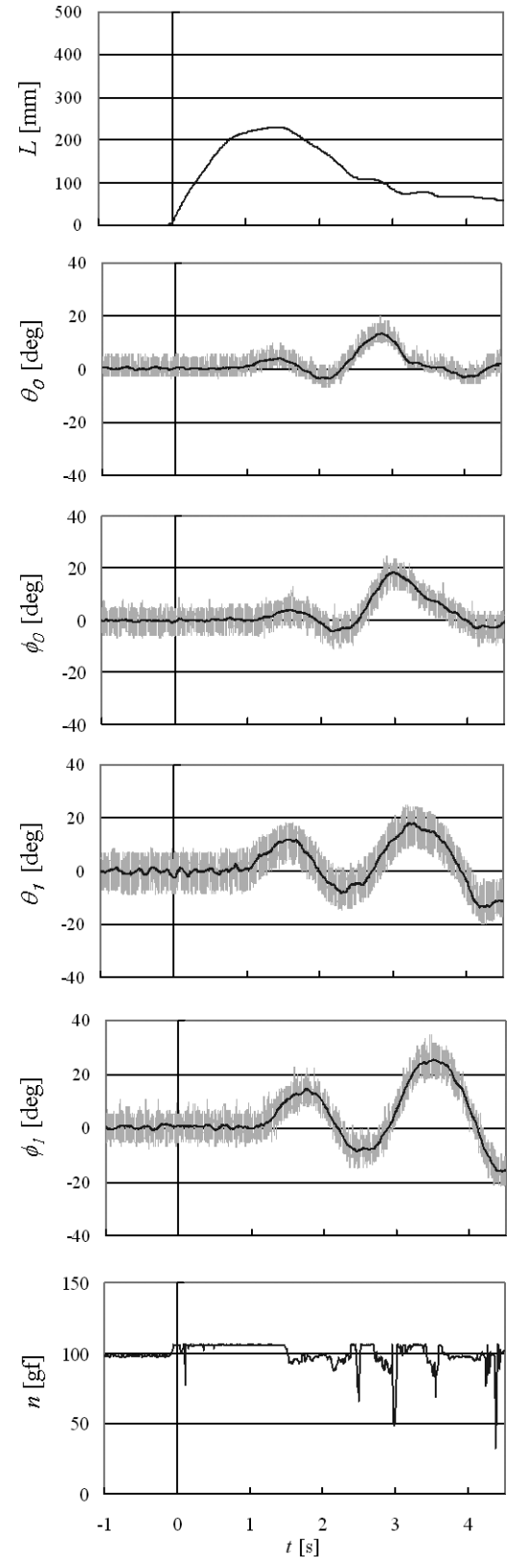

第 9 図 P 制御による実験結果

4.2 実験結果 第 7 図〜第 9 図に, 次の制御パラメー タおよび設定張力 $n$ による実験結果を示す．

(i) D 制御 $\quad k_{p}=0, k_{d}=2, \quad n=60[\mathrm{gf}]$

(ii) $\mathrm{PD}$ 制御 $\quad k_{p}=k_{d}=3, \quad n=60[\mathrm{gf}]$

(iii) $\mathrm{P}$ 制御 $\quad k_{p}=2, k_{d}=0, \quad n=100[\mathrm{gf}]$

各図において，第 1 列目はテザー長さ $L$, 第 2 列目および 第 3 列目は 0 軸回りのベース姿勢角速度 $\omega_{0}$ およびアー 么角 $\phi_{0}$, 第 4 列目および第 5 列目は 1 軸回りの $\omega_{1}$ およ び $\phi_{1}$, 第 6 列目はテザー張力 $n$ を表す . ただし, 第 7 図 の (i) D 制御では, 装置の不具合により, テザー張力測定 データを得ることができなかった。また，(i) D 制御およ び (ii) PD 制御では, 振動ジャイロセンサー (CRS03-02・ シリコンセンシングジャパン社製) を用いて姿勢角速度を 検出, (iii) P 制御では, ファイバ・オプティック・ジャイ
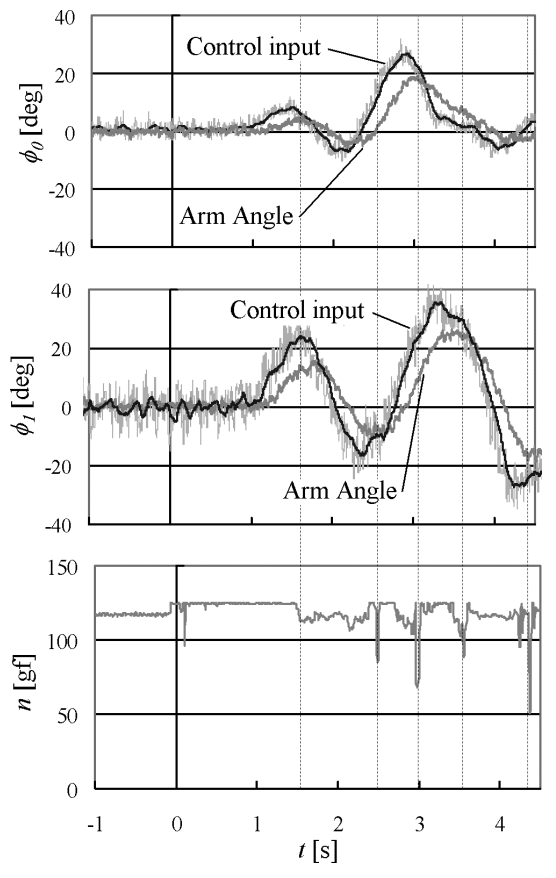

第10図 P 制御によるアーム動作

口 (JG-108FD1・日本航空電子社製) を用いて各軸回りの 姿勢角を検出している.このため，第 9 図の第 2 列目およ び第 4 列目は，姿勢角 $\theta_{0}$ および $\theta_{1}$ を表す . ジャイロセン サーおよびポテンショメータによる計測值はノイズが大き いため, $100 \mathrm{~ms}$ の平均值を同時に示している.横軸は時間 軸であり，落下開始時点を $t=0$ とする. 微小重力状態は 約 4.5 秒程度であり, 兴の後落下カプセルは制動状態とな るため, 各図において $0<t<4.5$ の間が微小重力状態と なる .

第 7 図の $\mathrm{D}$ 制御では, テザー長さ $L$ が $t=1.6$ 付近で 不連続的に変化している.これは, ロボットがカプセル上 部に衝突したためである. また , テザー長さ $L$ が $t=3.7$ 付近でも不連続的に変化している.これは, ロボットが回 収され，カプセル底部に到達したためである．ロボットの 挙動に関して, $t=0$ の射出時に外乱が発生しているが, 光 の後姿勢が維持されている. また, 最終的な大きな挙動は, カプセル底部に到達したためである .このことから D 制御 では, 外乱の発生による姿勢変動を補償し, 目標姿勢を維 持できることがわかる .

第 8 図の PD 制御では, テザー長さ $L$ の変化は, 微小 重力状態である間, 連続的に変化している.すなわち, 微 小重力状態の間に, ロボットがスムーズに伸展回収されて いることがわかる.ロボットの挙動に関しては, $t=0$ での 射出時に外乱が発生し, 兴の後振動が発生しているが, 減 衰している.しかし，第 7 図の (i) D 制御の場合と比較す ると，弚の挙動は大きく，姿勢制御は行われているが，目 標姿勢への収束性が低いといえる．また，初期のアーム動 作が大きいときに, 張力変動が大きい .

第 9 図の $\mathrm{P}$ 制御では, テザー長さ $L$ の变化は, 連続的 に変化した後に，やや不連続に変化している．この不連続 

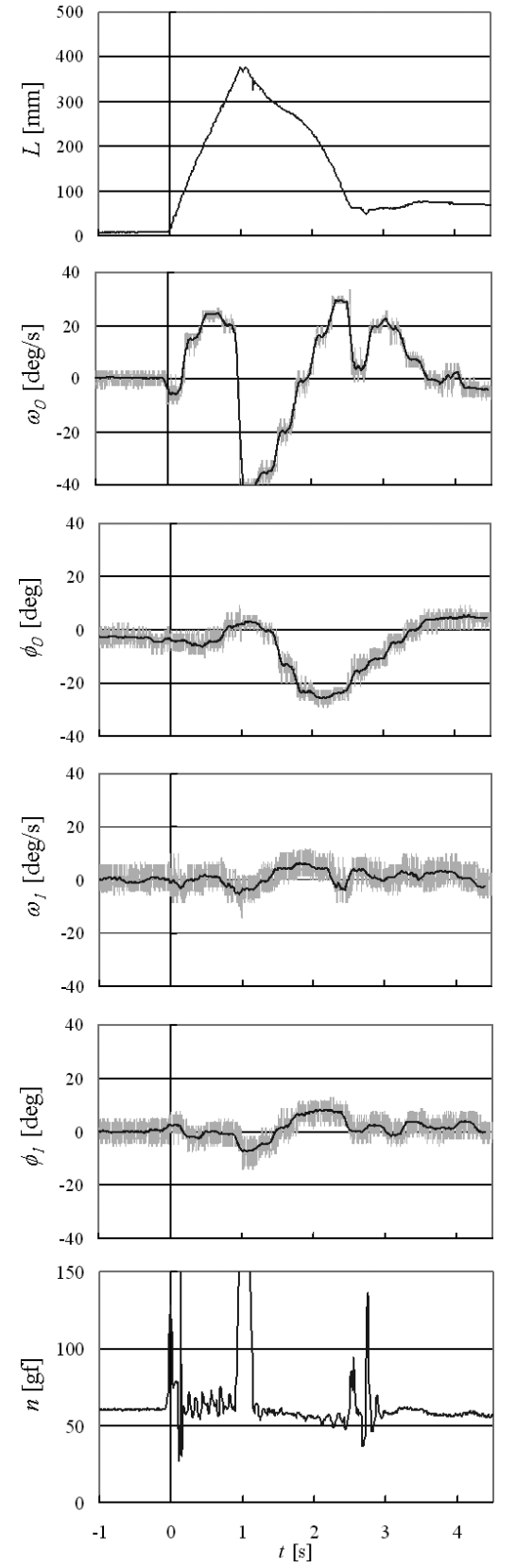

第11 図 0 軸 $\mathrm{P}$ 制御・1 軸 D 制御の実験結果

部分は, ロボットが回収され, カプセル底部に到達したた めである.ロボットの挙動に関して，この場合は $t=0$ で の射出時の外乱発生はなく, 途中から振動が発生し, 増幅 している.第 8 図の (ii) PD 制御の場合とあわせて考え ると, 式 (5) の第 1 項は回転運動の振動を増幅させている 可能性がある . これは，アーム動作によるテザー張力の変 動, およびモータの応答特性の遅延が原因であると考えら れる.第 9 図に示す $\mathrm{P}$ 制御の結果について，第 10 図に制 御指令角とアーム角，およびテザー張力を示す .この図か ら，アーム動作が大きい場合に, テザー張力変動が起きて いることがわかる．また，振動のピークにおいて，アーム 角は姿勢角から $100 \mathrm{~ms}$ 以上の遅れがあること, 制御ゲイ ンは $k_{p}=2$ であるがアーム角は制御指令角より小さいこ
とがわかる .

式 (5) の復元項に起因する回転運動の振動発生について 検証するため, アーム駆動二軸の一軸 (0 軸) を $\mathrm{P}$ 制御と し，他軸 (1 軸) を D 制御として実験を実施した . 結果を 第 11 図に示す .この実験では, テザー長さ $L$ からロボッ 卜は, $t=1.0$ 付近でカプセル上部に衝突, $t=2.4$ 付近で カプセル底部に到達している．光してロボットの挙動は, $\mathrm{P}$ 制御を行っている軸は回転運動の振動か増幅し，D制御を 行っている軸は回転運動がほとんど発生していない，また， $\mathrm{P}$ 制御を行っている軸のアーム動作が大きい場合に , 大き なテザー張力変動が起きている .

\section{5. 結言}

本論文では，これまでに理論解析を行ってきたテザ一宇 宙ロボットの姿勢制御手法の検証・評価を目的として, 日 本無重量総合研究所 (MGLAB) において落下塔による微 小重力実験を行った . まずテザー宇宙ロボットの姿勢制御 に必要となる機構を設計し, 落下カプセル内で実験可能な 小型・軽量かつ自律系となる実験装置を製作した . 光して， 考案した機構に実装可能な制御手法を設計した。また姿勢 制御をテザー張力が作用する伸展回収中に行うため，落下 実験の特徵を考慮した伸展回收装置を製作した 。

テザー宇宙ロボットの姿勢制御は, アーム動作によるテ ザー張力の回転力を制御することにより行う．テザー張力 がテザー先端ロボットに作用する場合 , テザー延長線上に ロボット質量中心位置があると安定な平衡状態である .こ の平衡状態から逸脱すると, アーム動作がない場合でも, 平 衡状態方向にテザー張力が作用する．このため, 減衰力を 発生させるアーム動作により，姿勢制御は可能となる．こ の原理を利用した姿勢制御効果は, 微小重力実験により検 証・評価された .

姿勢制御精度を高めるためには, アーム動作により復元 力を大きくすることが考えられる．しかし，本実験装置の 制御系設計において, ロボットの三軸姿勢を検出するのは 困難であること,さらに大きな姿勢変動またはアーム動作 がある場合，機構を考慮したアーム動作を行う必要が生じ ること，またテザー張力を計測する必要があること，など の問題がある.さらに, 微小重力実験結果からは, アーム動 作が大きいと張力変動が発生すること, 制御に遅れが生じ ると不安定な挙動となること，が確認された . ここでアー ム動作による張力变動は, テザー宇宙ロボットの姿勢制御 において特徵的な現象であり，とくに制御系設計において 考慮する必要がある。

\section{参 考 文 献}

1）稻場典康，小田光茂, 西田信一郎, 林 正人: 宇宙ロボットによ る浮遊衛星捕獲のシステム設計, 日本航空宇宙学会論文集, 51 (2003), pp. 469-474.

2) 能見公博, 内山 勝 : テザーを利用した宇宙ロボットの提案と挙 動解析, 第 13 回日本ロボット学会学術融演会予稿集, 1995, pp. 397-398.

3) Rupp, C. C. and Laue, J. H.: Shuttle/Tethered Satellite System, J. Astronaut. Sci., 26 (1978), pp. 1-17. 
4) Bainum, P. M. and Kumar, V. K.: Optimal Control of the Shuttle-Tethered-Subsatellite System, Acta Astronaut., 7 (1980), pp. 1333-1348.

5) Fujii, H. and Ishijima, S.: Mission-Function Control for Deployment and Retrieval of a Subsatellite, J. Guid. Control Dynam., 12 (1989), pp. 243-247.

6) Modi, V. J., Lakshmanan, P. K. and Misra, A. K.: On the Control of Tethered Satellite System, Acta Astronaut., 26 (1992), pp. 411-423.

7) Lang, D. D. and Nolting, R. R.: Operation with Tethered Space Vehicles, Gemini Summary Conference, Houston, Texas, NASA SP-138, 1967, pp. 55-66.

8) Bergamaschi, S., Bonon, F., Merlina, P. and Morana, M.: Theoretical and Experimental Investigation of TSS-1 Dynamics, 44th Congress of the International Astronautical Federation, Graz, Austria, Paper No. IAF-93-A.3.21, 1993.

9) 板橋孝昌, 平山 寛, 八坂哲雄: 超小型テザー衛星 QTEX (1) プ ロジェクト概要，第 48 回宇宙科学技術連合講演会 , 2004, 2 D01.
10）能見公博, Nenchev, D. N., 内山 勝 : キャスティングによるテ ザーロボットの宇宙空間移動，機論 C , 64 (1998), pp. 629-635.

11）森治, 松永三郎: 群型テザード衛星システムの回転運動制御, 日本航空宇宙学会論文集，50 (2002), pp. 109-117.

12) Ishige, Y., Kawamoto, S. and Kibe, S.: Study on Electrodynamic Tether System for Space Debris Removal, 53th International Astronautical Congress, Houston, Texas, IAF-02A.7.04, 2002.

13) Nohmi, M., Nenchev, D. N. and Uchiyama, M.: Tethered Robot Casting Using a Spacecraft Mounted Manipulator, AIAA J. Guid. Control Dynam., 24 (2001), pp. 827-833.

14) Umetani, Y. and Yoshida, K.: Resolved Motion Rate Control of Space Manipulators with Generalized Jacobian Matrix, IEEE Trans. Robotics Automation, 5 (1989), pp. 303-314.

15) Vafa, Z. and Dubowsky, S.: On the Dynamics of Space Manipulators Using the Virtual Manipulator, with Applications to Path Planning, J. Astronaut. Sci., 38 (1990), pp. 441-472.

16) http://www.mglab.co.jp/ 